\title{
A REVIEW OF THE EXERGY ANALYSIS OF THERMAL MANAGEMENT SYSTEMS IN ELECTRIC VEHICLES
}

\author{
M. Sreekanth ${ }^{*} \bowtie$, M. Feroskhan 2 (iD) \\ ${ }^{*}$ Electric Vehicles Incubation, Testing and Research Center \& School of Mechanical Engineering, \\ Vellore Institute of Technology Chennai, Chennai, Tamilnadu, India \\ ${ }^{2}$ School of Mechanical Engineering Vellore Institute of Technology Chennai, Chennai, Tamilnadu, \\ India
}

DOI: https://doi.org/10.29121/ijetmr.v8.i4.2021.917

Article Citation: M. Sreekanth, and M. Feroskhan. (2021). A REVIEW OF THE EXERGY ANALYSIS OF THERMAL MANAGEMENT SYSTEMS IN ELECTRIC VEHICLES.

International Journal of Engineering Technologies and Management Research, 8(4), 40-45.

https://doi.org/10.29121/ijetmr.v8 i4.2021.917

Published Date: 24 April 2021

Keywords:

Electric Vehicle

Thermal Management System

Exergy Analysis

2nd Law Analysis

\begin{abstract}
Exergy analysis is an advanced and a fair method of performance evaluation compared to the traditional energy analysis. In this article, a review of the exergy analysis studies carried out in the field of thermal management of electric vehicles is conducted. Studies conducted on battery, electric motor, cabin and electronics have been considered. It is noted that most of the work is done on battery thermal management. The nature of the work, methods used, parameters varied and parameters evaluated are listed. It can be found that the amount of work carried out in this field is very much limited. Hence, the scope of future work is more and is described in the conclusions.
\end{abstract}

\section{INTRODUCTION}

With the advent of solar and wind energy becoming competitive with fossil fuels in matters of cost, the world is rising the standards are encouraging every country to aim at lowering CO2 emissions as well as pollution. Many developed and developing countries have signed the Paris agreement which emphasizes on the reduction of CO2 emissions and foot print. One major action towards achieving that goal is to carry out any activity with improved efficiency. Activities can be anything from power generation, mobility, manufacturing, distribution etc.

A major paradigm shift is brought about by the development of electric vehicles, which are efficient in operation, produce lower amount of noise and do not cause pollution at the site of operation. Many countries have set themselves an ambitious target of converting most of their road fleet from internal combustion engines to electric vehicles. This is made possible due to cheaper electric energy from renewable sources. However, currently there are certain issues which need attention. Firstly, electric vehicles (EVs) are expensive at the first cost. Further, there is a need to build the EV eco-system comprising of charging, repair, service and maintenance infrastructure. These need to be addressed by policy makers.

A major issue with EVs is the thermal management. The main components which are the battery [1] and motor [2] need to be operated within a narrow window of temperature. Batteries are not allowed to heat up beyond $50^{\circ} \mathrm{C}$

(C) 2021 The Author(s). This is an open access article distributed under the terms of the Creative Commons Attribution License, which permits unrestricted use, distribution, and reproduction in any medium, provided the original author and source are credited. 
which can result in thermal run away. Also, motors are not allowed to over-heat beyond $75^{\circ} \mathrm{C}$ which can lead to ceasing of the magnetic strength in the Permanent Magnet Synchronous Motors (PMSM) often used in EVs. There are several methods adapted to meet the stringent thermal requirements of the batteries as well as the motor. Often, very little attention is paid to the cabin management as the knowledge about cabin thermal management is available from the regular internal combustion engines. Also, the electronics is not considered in the overall picture but they too are crucial and need to be kept at a temperature below $75^{\circ} \mathrm{C}$ for proper functioning. Batteries are cooled using refrigeration system, which is already available in the automobile. Cooling methods involving phase change materials too are adopted. Motors are cooled by passing a coolant through the stator channels or jackets. Small motors are cooled using air while larger ones are cooled using coolants having higher heat capacity. Often, cooling systems add to the bulk of the EV and hence they need to be as small and light as possible and at the same time need to be effective.

From thermodynamics, it is known that any process involves irreversibilities [3]. The same applies to cooling processes which are basically heat exchange processes happening at finite temperature differences. This brings about irreversibility, entropy generation and hence exergy loss. Exergy loss, being the loss of useful energy, results in unnecessary loss of high-quality energy. A knowledge of the cause and location of exergy loss can help the designer in minimizing the exergy loss, resulting in better performance and hence lower initial and operational cost. The environmental impact too can be reduced by adopting the good practices recommended by a detailed exergy analysis [4].

There have been several studies conducted on the effectiveness of cooling methods, mostly on EV batteries, followed by EV motors. They range from investigating an innovative cooling method, evaluating its effectiveness experimentally or by simulation or by both methods. In all these studies, only energy analysis is carried out. A simple energy analysis does not distinguish between the low and high quality of energy. Hence exergy-based evaluation methods, also known as 2nd law analysis is a preferred way to evaluate how effective a method is. Exergy method is based on the amount of useful energy destroyed, which could have been put to a better use. A detailed exergy analysis identifies the methods, components which are responsible for excessive exergy destruction. This could help in modifying the method or the operating parameters so as to minimize the exergy destruction.

In this review article, a summary of the exergy studies is made and area where further study is needed is identified.

\section{STUDIES ON EXERGY ANALYSIS}

One of the first to work on the exergy analysis of thermal management of EVs is the group of Hamut [5],[9]. In Hamut et al. [5], the authors carried out a simulation of cooling in EVs and Hybrid Electric Vehicles (HEVs). They have considered three different cooling schemes and performed an exergy analysis and identified the one with the highest exergetic coefficient of performance (COP). They considered a vapour compression refrigeration system for the cabin and a liquid coolant for the battery. A heat load of $5 \mathrm{~kW}$ is taken as basis of the study. They also involved an analytical solution meant to estimate the temperature distribution inside the battery.

Hamut et al. [6] have included range extended EVs in their study. They have taken one cooling system and varied its evaporator, condenser temperatures and heat load as well as compressor efficiency to carry out a parametric study. The performance was evaluated by computing the COP, exergy efficiency and the environmental impact.

Hamut et al. [7] now considered the various components of the battery (Li-Ion) and conducted an exergoeconomic study and identified the component which is mostly responsible for exergy destruction. They have also carried out a life cycle analysis. Such studies are useful to assess the worthiness of a cooling method throughout their life.

Hamut et al. [8] have now considered a HEV involving a Li-Ion battery and the cooling method is the same as earlier. In this work, they have carried out an exergo-economic, environmental impact analysis as well as optimization studies to arrive at lowest cost, lowest environmental impact and highest exergy efficiency. For this they considered various components as well as exergy efficiency as a parameter.

Hamut et al. [9] have now considered the different operational conditions like compressor speed, condenser pressure drop, evaporator and condenser pressures, and heat load. They have evaluated the performance using energetic and exergetic COP and exergy destruction. 
Javani et al. [10] have considered phase change materials for battery cooling, in addition to vapour compression system for cabin cooling. They carried out simulations involving amount of phase change material, evaporator and condenser temperature, compressor pressure and evaluated the performance of this cooling system by estimating the exergy efficiency, COP, emissions, sustainability, and also optimized the cost.

Zhang et al. [11] have included aspects of psychrometry (like humidity, recirculation, ventilation) in their analysis of an EV. They too considered Li-Ion battery and the performance was evaluated by estimating the cooling load, exergy flow, exergy loss, and loss due to friction.

Tian et al. [12] proposed a new thermal management method in which the heat generated in the motor is used in the heat pump for maintaining the cabin temperature. This is useful in cold climate. They have conducted experiments as well as simulation and estimated the thermos-economics, exergy destruction and the COP. The parameters considered are fraction of expansion valve opening, two cooling configurations and refrigerant charge.

Zhang et al. [13] have carried out simulations for the system involving passenger cabin and battery. Using their model, they could estimate temperatures at various locations and the exergy loss of the system. The study was conducted during cooling as well as heating and demisting modes. Variable compressor speeds too were considered.

Tang et al. [14] have conducted experiments as well as simulation to study the cabin and battery cooling systems having a heat load of $3.6 \mathrm{~kW}$. They considered air flow rate, flow velocity, compressor speed, ambient temperature and extent of

Table 1: Summary of studies carried out on exergy analysis of thermal management in electric vehicles

\begin{tabular}{|c|c|c|c|c|c|c|c|c|}
\hline $\begin{array}{c}\text { S. } \\
\text { No }\end{array}$ & Author/Year & $\begin{array}{l}\text { EV or } \\
\text { HEV }\end{array}$ & $\begin{array}{c}\text { Nature of } \\
\text { Work }\end{array}$ & $\begin{array}{l}\text { Cooling } \\
\text { System }\end{array}$ & $\begin{array}{c}\text { Cooling } \\
\text { Load, } \\
\text { kW }\end{array}$ & $\begin{array}{c}\text { Component } \\
\text { Studied }\end{array}$ & Parameters & $\begin{array}{l}\text { Evaluation } \\
\text { Parameters }\end{array}$ \\
\hline 1 & $\begin{array}{l}\text { Hamut, } \\
2012 \text { a }\end{array}$ & $\begin{array}{l}\text { EV \& } \\
\text { HEV }\end{array}$ & Simulation & $\begin{array}{l}\text { Refrigerant, } \\
\text { VCS, liquid } \\
\text { coolant for } \\
\text { battery }\end{array}$ & 5 & $\begin{array}{l}\text { Li-ion } \\
\text { Battery }\end{array}$ & $\begin{array}{l}\text { 3 different } \\
\text { systems, } \\
\text { ambient } \\
\text { temperature } \\
\text { and time }\end{array}$ & $\begin{array}{c}\mathrm{COP}_{\mathrm{en}}, \mathrm{COP}_{\mathrm{ex}} \\
\mathrm{S}_{\mathrm{gen}} \\
\text { Temperature } \\
\text { distribution }\end{array}$ \\
\hline 2 & $\begin{array}{l}\text { Hamut, } \\
2012 \text { b }\end{array}$ & $\begin{array}{c}\text { HEV } \\
\text { (Range } \\
\text { extended } \\
\text { EV) }\end{array}$ & Simulation & $\begin{array}{l}\text { Refrigerant, } \\
\text { VCS, liquid } \\
\text { coolant for } \\
\text { battery }\end{array}$ & 5 & $\begin{array}{l}\text { Li-ion } \\
\text { Battery }\end{array}$ & $\begin{array}{c}\mathrm{T}_{\text {eva, }}, \mathrm{T}_{\text {cond }} \text {, heat } \\
\text { load, } \eta_{\text {comp }},\end{array}$ & $\begin{array}{c}\text { COP, } \\
\text { Component } \\
\text { wise exergy } \\
\text { efficiency, } \\
\text { environmental } \\
\text { impact } \\
\end{array}$ \\
\hline 3 & $\begin{array}{l}\text { Hamut, } \\
2014 \text { a }\end{array}$ & HEV & Simulation & $\begin{array}{l}\text { Refrigerant, } \\
\text { VCS, liquid } \\
\text { coolant for } \\
\text { battery } \\
\end{array}$ & - & $\begin{array}{l}\text { Li-ion } \\
\text { Battery }\end{array}$ & $\begin{array}{c}\text { Battery } \\
\text { components }\end{array}$ & $\begin{array}{c}\text { Exergo- } \\
\text { economic, life } \\
\text { cycle analysis }\end{array}$ \\
\hline 4 & $\begin{array}{l}\text { Hamut, } \\
2014 \text { b }\end{array}$ & HEV & Simulation & $\begin{array}{l}\text { Refrigerant, } \\
\text { VCS, liquid } \\
\text { coolant for } \\
\text { battery }\end{array}$ & - & $\begin{array}{l}\text { Li-ion } \\
\text { Battery }\end{array}$ & $\begin{array}{c}\text { Various } \\
\text { components, } \\
\text { exergy } \\
\text { efficiency }\end{array}$ & $\begin{array}{c}\text { Exergo- } \\
\text { economic, } \\
\text { environmental } \\
\text { analysis, } \\
\text { multi- } \\
\text { objective } \\
\text { optimization, } \\
\text { exergy } \\
\text { efficiency, } \\
\text { total cost, } \\
\text { environmental } \\
\text { impact }\end{array}$ \\
\hline 5 & $\begin{array}{l}\text { Hamut, } \\
2014 \text { c }\end{array}$ & HEV & Simulation & $\begin{array}{l}\text { Refrigerant, } \\
\text { VCS, liquid }\end{array}$ & - & $\begin{array}{c}\text { Li-ion } \\
\text { Battery }\end{array}$ & $\begin{array}{l}\text { Teva, Tcond, } \\
\text { compressor } \\
\text { speed, heat }\end{array}$ & $\begin{array}{c}\mathrm{COP}_{\mathrm{en}}, \mathrm{COP}_{\mathrm{ex}} \\
\text { exergy } \\
\text { destruction }\end{array}$ \\
\hline
\end{tabular}




\begin{tabular}{|c|c|c|c|c|c|c|c|c|}
\hline & & & & $\begin{array}{c}\text { coolant for } \\
\text { battery }\end{array}$ & & & $\begin{array}{l}\text { load, } \\
\text { condenser } \\
\text { pressure } \\
\text { drops }\end{array}$ & \\
\hline 6 & Javani, 2014 & HEV & Simulation & $\begin{array}{l}\text { Refrigerant, } \\
\text { VCS, liquid } \\
\text { coolant for } \\
\text { battery, } \\
\text { and phase } \\
\text { change } \\
\text { material }\end{array}$ & 5 & $\begin{array}{l}\text { Li-ion } \\
\text { Battery }\end{array}$ & $\begin{array}{c}\text { Different } \\
\text { components, } \\
\text { PCM mass } \\
\text { fraction, } \mathrm{T}_{\text {eva }} \\
\mathrm{T}_{\text {cond }}, \mathrm{P}_{\text {comp }}\end{array}$ & $\begin{array}{l}\text { Optimization, } \\
\text { exergy } \\
\text { efficiency, } \\
\text { COP, exergy } \\
\text { destruction, } \\
\text { emissions, } \\
\text { sustainability, } \\
\text { cost }\end{array}$ \\
\hline 7 & Zhang, 2014 & EV & Simulation & $\begin{array}{l}\text { Phase } \\
\text { change } \\
\text { material }\end{array}$ & 0.45 & $\begin{array}{l}\text { Li-ion } \\
\text { Battery }\end{array}$ & $\begin{array}{c}\text { Tamb, } \\
\text { ventilation } \\
\text { rate, humidity, } \\
\text { heat } \\
\text { generation } \\
\text { rate } \\
\end{array}$ & $\begin{array}{l}\text { Cooling load, } \\
\text { exergy flow, } \\
\text { friction loss }\end{array}$ \\
\hline 8 & Tian, 2019 & EV & $\begin{array}{c}\text { Experiment } \\
\& \\
\text { Simulation }\end{array}$ & $\begin{array}{l}\text { Refrigerant, } \\
\text { VCS, liquid } \\
\text { coolant for } \\
\text { battery }\end{array}$ & 5 & $\begin{array}{l}\text { Battery, } \\
\text { also motor } \\
\text { for waste } \\
\text { heat } \\
\text { recovery, } \\
\text { not for } \\
\text { cooling }\end{array}$ & $\begin{array}{c}\text { Expansion } \\
\text { valve opening, } \\
\text { basic and new } \\
\text { configurations, } \\
\text { refrigerant } \\
\text { charge }\end{array}$ & $\begin{array}{c}\text { Proposed a } \\
\text { new TMS with } \\
\text { heat pump, } \\
\text { battery } \\
\text { cooling and } \\
\text { motor waste } \\
\text { heat recovery. } \\
\text { Thermo- } \\
\text { economics, } \\
\text { exergy } \\
\text { destruction, } \\
\text { COP }\end{array}$ \\
\hline 9 & Zhang, 2020 & EV & Simulation & $\begin{array}{l}\text { Refrigerant, } \\
\text { VCS, liquid } \\
\text { coolant for } \\
\text { battery }\end{array}$ & - & $\begin{array}{l}\text { Cabin, } \\
\text { Battery }\end{array}$ & $\begin{array}{c}\text { Different } \\
\text { operational } \\
\text { modes like } \\
\text { heating, } \\
\text { cooling, de- } \\
\text { misting, } \\
\text { compressor } \\
\text { speed }\end{array}$ & $\begin{array}{l}\text { Temperature } \\
\text { at various } \\
\text { locations, } \\
\text { exergy loss of } \\
\text { system }\end{array}$ \\
\hline 10 & Tang, 2020 & EV & $\begin{array}{c}\text { Experiment } \\
\& \\
\text { Simulation }\end{array}$ & $\begin{array}{l}\text { Refrigerant, } \\
\text { VCS, liquid } \\
\text { coolant for } \\
\text { battery }\end{array}$ & $\begin{array}{l}\text { Heating } \\
\text { load, } \\
3.6 \mathrm{~kW}\end{array}$ & $\begin{array}{c}\text { Cabin, } \\
\text { battery }\end{array}$ & $\begin{array}{l}\text { Air flow rate, } \\
\text { flow speed, } \\
\text { compressor } \\
\text { speed, } \mathrm{T}_{\mathrm{amb}} \\
\text { expansion } \\
\text { valve opening }\end{array}$ & $\begin{array}{c}\text { Compressor } \\
\text { power, } \\
\text { heating } \\
\text { capacity, } \\
\text { exergy loss, } \\
\text { exergy } \\
\text { efficiency, } \\
\text { exergy } \\
\text { destruction in } \\
\text { several } \\
\text { components } \\
\end{array}$ \\
\hline
\end{tabular}

exhaust valve opening. They evaluated the performance by compressor power consumed, heating capacity, exergy loss, exergy efficiency, and exergy destruction in various components of the cooling system. 
All the studies described above are summarized in Table 1. In the studies discussed, most of the exergy destruction is found to happen in the compressor followed by heat exchangers like evaporator, condenser and then in the expansion valve. The analysis involves mass, energy, exergy and entropy balances. Mass and energy are also conserved. Equations were framed for each system based on [3] and they were solved either by using mathematical software package like Engineering Equation Solver (EES) or by developing an in-house code.

\section{CONCLUSION}

It can be seen that the number of studies is very much limited and most of them are simulations.

From the above literature survey, the following can be concluded:

1) There is very limited study on performance evaluation of electric vehicle thermal management-based 2nd law analysis.

2) Among the available studies, almost all the work is done on battery thermal management.

3) Few works included cabin thermal management along with that of the battery.

4) There is no study on motor thermal management based on 2nd law analysis.

5) No study considered the comprehensive thermal management of cabin+battery+motor+electronics.

6) Very limited studies using phase change materials were carried out.

Scope for further research:

1) 2nd law analysis of electric vehicle motor thermal management can be carried out.

2) Among the battery's studies, only Li-Ion battery is considered. Hence other competing battery candidates can be studied.

3) Comprehensive thermal management studies based on 2nd law analysis (for cabin+battery+motor+electronics) can be studied.

\begin{tabular}{|c|c|}
\multicolumn{2}{c}{ NOMENCLATURE } \\
\hline Symbol & Full Form \\
\hline EV & Electric Vehicle \\
\hline HEV & Hybrid Electric Vehicle \\
\hline VCS & Vapour Compression System \\
\hline COP $_{\text {en }}$ & Energetic COP \\
\hline COP $_{\text {ex }}$ & Exergetic COP \\
\hline$S_{\text {gen }}$ & Entropy Generated \\
\hline $\mathrm{P}_{\text {comp }}$ & Compressor pressure ratio \\
\hline $\mathrm{T}_{\mathrm{amb}}$ & Ambient Temperature \\
\hline
\end{tabular}

\section{SOURCES OF FUNDING}

This research received no specific grant from any funding agency in the public, commercial, or not-for-profit sectors.

\section{CONFLICT OF INTEREST}

The author have declared that no competing interests exist.

\section{ACKNOWLEDGMENT}

None. 


\section{REFERENCES}

[1] Kumar P, Chaudhary D, Varshney P, Varshney U, Yahya SM, Rafat Y. Critical review on battery thermal management and role of nanomaterial in heat transfer enhancement for electrical vehicle application. Journal of Energy Storage. 1; 32:102003, 2020.

[2] Tikadar A, Johnston D, Kumar N, Joshi Y, Kumar S. Comparison of electro-thermal performance of advanced cooling techniques for electric vehicle motors. Applied Thermal Engineering. 25; 183:116182., 2021.

[3] Boles M, Cengel Y. An Engineering Approach. New York: McGraw-Hil l Education. 2014.

[4] Kotas TJ. The exergy method of thermal plant analysis. Elsevier; 2013.

[5] Hamut HS, Dincer I, Naterer GF. Performance assessment of thermal management systems for electric and hybrid electric vehicles. International Journal of Energy Research. 37(1):1-2, 2012

[6] Hamut HS, Dincer I, Naterer GF. Exergy analysis of a TMS (thermal management system) for range-extended EVs (electric vehicles). Energy. 1;46(1):117-25, 2012.

[7] Hamut HS, Dincer I, Naterer GF. Exergoenvironmental analysis of hybrid electric vehicle thermal management systems. Journal of Cleaner Production. 15; 67:187-96, 2014.

[8] Hamut HS, Dincer I, Naterer GF. Analysis and optimization of hybrid electric vehicle thermal management systems. Journal of Power Sources. 1; 247:643-54, 2014.

[9] Hamut HS, Dincer I, Naterer GF. Exergetic and energetic evaluations of hybrid electric vehicle thermal management systems. International Journal of Exergy.1;14(3):341-63, 2014.

[10] Javani N, Dincer I, Naterer GF, Yilbas BS. Exergy analysis and optimization of a thermal management system with phase change material for hybrid electric vehicles. Applied Thermal Engineering.1;64(1-2):471-82, 2014.

[11] Zhang X, Kong X, Li G, Li J. Thermodynamic assessment of active cooling/heating methods for lithium-ion batteries of electric vehicles in extreme conditions. Energy. 1; 64:1092-101, 2014.

[12] Tian Z, Gu B. Analyses of an integrated thermal management system for electric vehicles. International Journal of Energy Research. 43(11):5788-802, 2019.

[13] Zhang K, Li M, Yang C, Shao Z, Wang L. Exergy analysis of electric vehicle heat pump air conditioning system with battery thermal management system. Journal of Thermal Science, 29(2):408-22, 2020.

[14] Tang X, Guo Q, Li M, Jiang M. Heating Performance Characteristics of an Electric Vehicle Heat Pump Air Conditioning System Based on Exergy Analysis. Energies, 13(11):2868, 2020. 